\title{
Lifestyle Businesses in Rezekne Municipality
}

\author{
Iveta Dembovska \\ Faculty of Economics and Business \\ Management \\ Rezekne Academy of Technologies \\ Rezekne, Latvia \\ iveta.dembovska@rta.lv
}

\author{
Lienite Litavniece \\ Faculty of Engineering \\ Rezekne Academy of Technologies \\ Rezekne, Latvia \\ lienite.litavniece@rta.lv
}

\author{
Inese Silicka \\ Faculty of Economics and Business \\ Management \\ Rezekne Academy of Technologies \\ Rezekne, Latvia \\ inese.silicka@rta.lv
}

\begin{abstract}
In regional economy, creation of a system for development of small enterprises and lifestyle businesses is one of the strategies to promote entrepreneurship and targeted use of the local economic resources thus reducing the burden on public and local budgets. Lifestyle businesses are mainly established and maintained with the aim of providing a certain level of income, performing additional activities or developing the owner's hobby, and effectively using the local resources. The aim of the research is to explore the theoretical foundations of lifestyle businesses and potential for their creation and development, using lifestyle businesses of Rezekne municipality as a case. The following tasks were set for achieving the aim: to provide theoretical rationale for lifestyle businesses; to identify lifestyle businesses in Rezekne municipality; to study and analyse the motivation of lifestyle business owners to establish and develop business in Rezekne municipality.
\end{abstract}

Keywords-lifestyle business, local resources, Rezekne municipality.

\section{INTRODUCTION}

Latvia's economic growth in 2017 and 2018 has been considerably faster than in previous years. Exports, investments, private and public consumption are steadily growing. Export volumes have reached the highest level so far. Almost all sectors of the economy are experiencing growth. Overall, in the three quarters of 2018, gross domestic product (GDP) has increased by $4.7 \%$, which is even faster than in 2017, when GDP grew by $4.6 \%$. The goal of the Ministry of Economics is to ensure that Latvia becomes the choice for startups in the Baltic countries and to promote lifestyle entrepreneurship in Latvia. (Goal: 1000 new entrepreneurs) The main task suggested by these goals is to create preconditions for the smallest entrepreneurs to be able to carry out their economic activities without placing a significant burden on the public and municipal social budgets (e.g. provision of benefits to the socially disadvantaged persons) [6]. Specific support programs for this type of entrepreneurs are being implemented [7]. Currently, the solutions for business start-ups, including drawing up the regulation for small business ecosystem and start-ups, are being developed, while the discussion on regulation for lifestyle business is still ongoing.

The vision of the Ministry of Economics envisages promoting lifestyle entrepreneurship in Latvia stipulating that the lifestyle entrepreneurs are those having up to 3 employees and 12 thousand euros in turnover. The
Ministry of Economics expects that 1000 new lifestyles companies will be created in Latvia and the new companies will pay 1.8 million euros contributions to the state budget until 2020. [8]

The aim of the research is to explore the theoretical foundations of lifestyle business and potential for their creation and development, analysing the case of lifestyle businesses of Rezekne municipality.

The following tasks were set to achieve the aim: to provide theoretical rationale for lifestyle businesses;

- to identify lifestyle businesses in Rezekne municipality;

to study and analyse the motivation of lifestyle business owners to establish and develop business in Rezekne municipality.

\section{MATERIALS AND METHODS}

This article summarizes the results of the authors' research on the motivation for the creation and development of lifestyle businesses in Rezekne municipality.

The methods applied in the research: logical and constructive methods, scientific induction method, synthesis, monographic method and graphic method, sociological research method (survey).

Object of the research: lifestyle businesses.

Subject of the research: motivation for establishment and development of lifestyle businesses.

\section{RESULTS AND DISCUSSION}

The authors have chosen the research of lifestyle businesses for several reasons. Small businesses provide satisfaction of personal and family needs; they are more likely to succeed in realizing the initial idea; the opportunity to make a profit right away; working from any location, business can be kept going and moving forward managing it in distance; becoming owner of personal time resource, free planning of the individual daily schedule [9].

Collins English Dictionary defines lifestyle business as a small business in which the owner is more anxious to pursue interests that reflect his/her lifestyle than to make more than a comfortable living [10].

Marckettti, Niehm and Fuloria regarding lifestyle entrepreneurs note that they are "neither wealth seekers nor financially independent people who can do their hobby. These are individuals who own business and are

Print ISSN 1691-5402

Online ISSN 2256-070X

http://dx.doi.org/10.17770/etr2019voll.4111

(C) 2019 Iveta Dembovska, Lienite Litavniece, Inese Silicka. Published by Rezekne Academy of Technologies.

This is an open access article under the Creative Commons Attribution 4.0 International License. 
keen on doing business in close accordance with their personal values, beliefs, interests and hobbies" [5].

Some authors define lifestyle entrepreneurs as individuals who own and operate business closely aligned with their personal values, beliefs, and interests [11], [4]. This definition includes individual values and motivation to start a business.

Business with a limited growth potential is often considered a lifestyle company, and the founder's resources and borrowings are often sufficient to develop it. Lifestyle businesses are companies that are largely dependent on the founder's skills, personality, energy and contacts. Often, their founders express their business through personal talents, skills, flexible schedules, work with other family members, and work in the desired geographical location [3].

A lifestyle company is a company that is created and led by its founders, mainly for the purpose of maintaining a certain level of income and no more or establishing a foundation for enjoying a particular lifestyle.

A lifestyle business is one that focuses on supporting the owner's income and personal requirements rather than maximizing income.

The goal of a lifestyle business is to create a sustainable and pleasant work-life balance. The company must be profitable enough to allow the lifestyle that the owner wants without sacrificing personal life. Type of business can also be chosen based on personal interests, so that working hours are enjoyable [12].

Lifestyle entrepreneurs are often referred to as entrepreneurs engaged in their own hobby, so their business has a personalized approach [13].

Morris uses an entry and exit system approach to distinguish an individual entrepreneur, who may also be a lifestyle entrepreneur, from an interactive business process. Individual and organizational contexts, resources, environmental opportunities and unique business concepts are prerequisites for starting a lifestyle business. Possible outcomes of business processes permanent job, value creation, innovations (products, services, processes and technologies), profit or personal benefit, employment, business growth and success. Morris [2], Deacon and Firebaugh [1] have studied the link between general systems theory and business processes and have obtained an integrative input-output system model in a result (Fig.1).

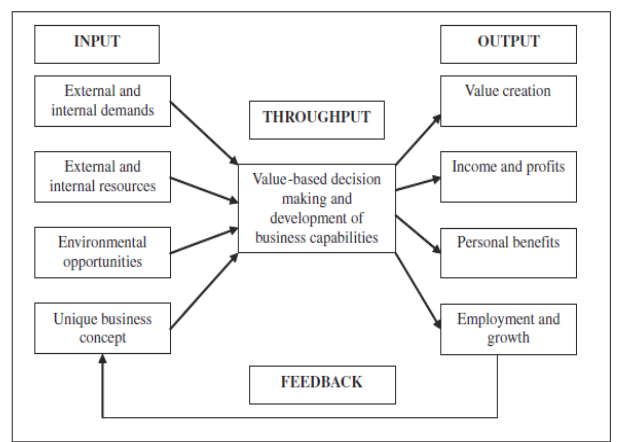

Fig 1. Conceptual model: The relationship of general systems theory to entrepreneurship [12], [13].

Largely, the middle class, especially in the regions, is the result of development of family businesses, which are often lifestyle businesses. These companies operate in a wide range of areas - service, trade, manufacturing, and others [14]. Intended support of the Ministry of Economics to the "lifestyle businesses" could mostly refer to the regional companies producing, for example, candles, sauna accessories, etc. However, there is a growing belief that lifestyle businesses should not be supported.

In the tourism sector in the regions, micro- and smallsized enterprises prevail. For these entities, tourism often is a lifestyle type of business, an additional activity, or a hobby. At the same time, the requirements imposed on such companies do not differ from those imposed on large companies. In the survey conducted by the State Education Development Agency, entrepreneurs have indicated the following significant external factors affecting the overall performance of companies in the tourism sector: amendments in the regulatory enactments (72.3\%), improvements in the marketing strategy at national level (68.9\%), the wide-ranging tourism advertising campaign in the country (68.6\%), as well as changes in tourist demand for services $(66.9 \%)$ [15].

To find out the number of lifestyle businesses in Rezekne city, Rezekne municipality, and Vilani municipality, the authors have used several statistical sources. The database of the Food and Veterinary Service (hereinafter-FVS) on registered domestic producers was used (FVS registry code 45 - production at home) (see Table 1).

TABLE 1. NUMBER OF ENTERPRISES MANUFACTURING AT

HOME IN REZEKNE CITY, REZEKNE MUNICIPALITY AND

VILANI MUNICIPALITY ON 28 JANUARY 2019 (COMPILED BY THE AUTHORS BASED ON [16])

\begin{tabular}{|c|c|c|c|}
\hline Code & $\begin{array}{l}\text { Rezekne } \\
\text { muni- } \\
\text { ci-pality }\end{array}$ & $\begin{array}{l}\text { Vilani } \\
\text { muni- } \\
\text { ci-pality }\end{array}$ & $\begin{array}{l}\text { Rezekne } \\
\text { city }\end{array}$ \\
\hline $\begin{array}{l}\text { 45.2. Production of meat } \\
\text { products at home }\end{array}$ & 5 & 0 & 5 \\
\hline $\begin{array}{l}\text { 45.3. Production of dairy } \\
\text { products at home }\end{array}$ & 2 & 1 & 0 \\
\hline $\begin{array}{l}\text { 45.4. Processing of fishery } \\
\text { products at home }\end{array}$ & 3 & 0 & 2 \\
\hline $\begin{array}{l}\text { 45.5. Production of vegeta- } \\
\text { ble oils and fats at home }\end{array}$ & 0 & 0 & 0 \\
\hline $\begin{array}{l}\text { 45.7. Processing of plant } \\
\text { products at home }\end{array}$ & 12 & 1 & 9 \\
\hline $\begin{array}{l}\text { 45.8. Production of bread } \\
\text { and flour products at home }\end{array}$ & 4 & 2 & 3 \\
\hline $\begin{array}{l}\text { 45.9. Production of egg } \\
\text { products at home }\end{array}$ & 0 & 0 & 0 \\
\hline $\begin{array}{l}\text { 45.10. Production of spe- } \\
\text { cific food of animal origin } \\
\text { at home }\end{array}$ & 0 & 0 & 0 \\
\hline $\begin{array}{l}\text { 45.11. Production of soft } \\
\text { drinks and ice at home }\end{array}$ & $\overline{1}$ & $\overline{0}$ & 1 \\
\hline 45.12. Catering at home & 2 & 1 & 3 \\
\hline $\begin{array}{l}\text { 45.13. Production of api- } \\
\text { culture products at home }\end{array}$ & 0 & 0 & 0 \\
\hline $\begin{array}{l}\text { 45.14. Production of food } \\
\text { supplements and other } \\
\text { products of specific plant or } \\
\text { mixed origin at home }\end{array}$ & 0 & 0 & 0 \\
\hline Total & 28 & 5 & 23 \\
\hline
\end{tabular}


Some of companies operate in several areas, for example, providing both homemade meat products and home cooking. Therefore the numbers in Table 1 differ from the total number of companies. Overall, in Rezekne city there are 19, in Rēzekne municipality - 26, in Vilani municipality - 5 companies manufacturing at home.

However, it should be noted that the FVS data provides only information on food producers working at home, still, there are many lifestyle companies engaged in crafts, ceramics, and other activities. The authors had access to information on companies registered in LEARN (Rezekne Municipality Foundation for Local Economic Development) database. This database contains information not only about Rezekne municipality, but also about lifestyle businesses in Rezekne city and Vilani municipality (see Table 2).

TABLE2. NUMBER OF COMPANIES IN REZEKNE CITY, REZEKNE MUNICIPALITY AND VILANI MUNICIPALITY REGISTERED BY “LEARN” ON 28 JANUARY 2019 (COMPILED BY THE AUTHORS BASED ON [17])

\begin{tabular}{|c|c|}
\hline Type of activity & Number \\
\hline Meat production & 7 \\
\hline Vegetable production & 7 \\
\hline Processing of dairy products & 3 \\
\hline Herbal teas/ seasonings & 4 \\
\hline Egg production & 3 \\
\hline Fruit production & 15 \\
\hline Bakery & 2 \\
\hline Production of honey and apiculture products & 10 \\
\hline Fish production & 2 \\
\hline Confectionery & 7 \\
\hline Sushi & 1 \\
\hline Manufacture and sale of alcoholic beverages & 2 \\
\hline Handicrafts & 33 \\
\hline Ceramics & 13 \\
\hline Craftsmen & 20 \\
\hline Buckwheat production & 1 \\
\hline Total & 130 \\
\hline
\end{tabular}

Table 2 shows that there are 130 companies operating in the area under study. However, some of them operate in several fields, resulting in a numerical figure of 125 .

For the pilot survey, 13 companies operating in different fields were selected to determine what motivation of the entrepreneurs to operate businesses is and whether home producers/ self-employed persons/ one-person-owned companies, farms, commercial entities can be considered as lifestyle businesses. The authors intend to conduct an in-depth study in this area.
TABLE 3. CHARACTERISTICS OF THE RESPONDENTS BY DURATION OF OPERATIONS AND TYPE OF ACTIVITY (COMPILED BY THE AUTHORS BASED ON THE SURVEY)

\begin{tabular}{|l|l|l|l|}
\hline \multicolumn{2}{|l|}{ Duration of operation } & Type of activity & $\%$ \\
\hline Answers & $\%$ & Answers & 38.46 \\
\hline Up to 1 year & 23.08 & Production & 30.77 \\
\hline 1-3 years & 30.77 & Services & 30.77 \\
\hline 3-5 years & 15.38 & $\begin{array}{l}\text { Both production and } \\
\text { services }\end{array}$ & \\
\hline Over 5 years & 30.77 & S & \\
\hline
\end{tabular}

The breakdown of respondents by duration of operation and type of activity is equivalent to all response groups. $46.15 \%$ of respondents operate in the food sector and $53.85 \%$ - in the non-food sector. (Compiled by the authors based on the survey)

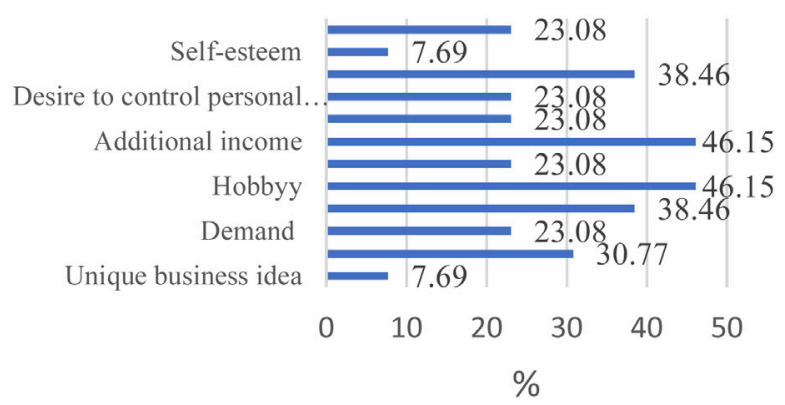

Fig.2. Motivation of respondents to start own business (Compiled by the authors based on the survey)

* Respondents could select multiple answers

Hobby (46.15\%) and an additional source of income $(46.15 \%)$ are the main motivations to start a business. In fact, the opportunity to earn with one's hobby already confirms the lifestyle. The desire to express oneself $(38.46 \%)$ and use of the environmental advantages $(38.46 \%)$ are other driving forces to start a business. It should be noted that Rezekne municipality has created tourism objects (Luznava Manor; Tourism and Water Recreation Centre Baka, etc.), thus promoting the attractiveness of the environment and enabling the nearby residents to create their own business offer. Other reasons are also important for the respondents.

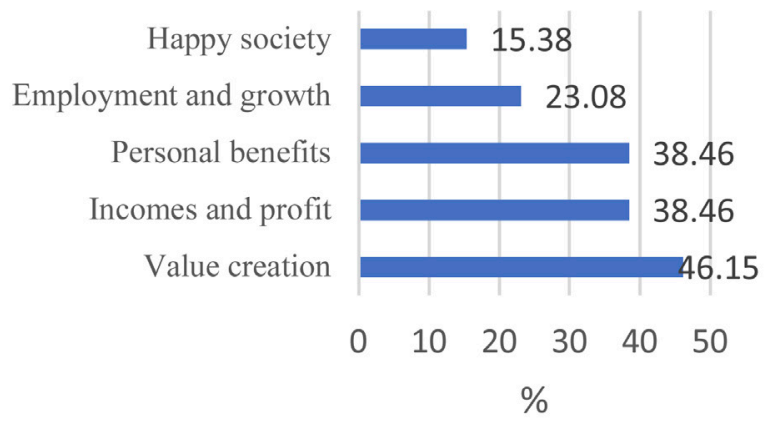

Fig. 3. The respondents' business result/ satisfaction (Compiled by the authors based on the survey)

* Respondents could select multiple answers 
Figure 3 shows that, in opinion of the respondents, it is important to create value $(46.15 \%)$, receive personal benefits (38.46\%), and ensure incomes and profit $(38.46 \%)$. In fact, it can be concluded that for the people, who engage starting a business, it is important to create the values.

Respondents were also offered to answer questions about their plans. Most of the respondents plan to expand their activities. This indicates that their operations are successful and the people feel demand, satisfaction, and income that motivates them to continue working.

\section{CONCLUSIONS}

Creating and developing lifestyle businesses around the world involves development of hobbies, satisfaction of personal and family needs, the desire to realize individual intentions, manage own time, earn extra income. In a result of the operations of lifestyle enterprises, the local resources, environmental opportunities are effectively used, and new and innovative products are created. In Rezekne municipality, Rezekne city, and Vilani municipality, lifestyle companies operate in various sectors - both in services and home production, as well as in crafts. Creating and developing their own small lifestyle businesses, the entrepreneurs have their longterm goals and plan to expand their operations in future. For the development of lifestyle businesses, it is often enough with the personal money of founders. In Latgale region, lifestyle entrepreneurs are people who turn their hobby into business and do business in close accordance with their personal desires and values, beliefs, interests. There are many people in Rezekne county who have interesting hobbies and who could create their own lifestyle companies, thus contributing to the economic development of Latgale region.

\section{REFERENCES}

[1] R. E. Deacon, and F. M. Firebaugh, Family resource management: Principles and applications (2nd ed.). Boston: Allyn \& Bacon, 1988

[2] M. Morris, Entrepreneurial intensity sustainable advantages for individuals, organizations, and societies.Westport, CT: Quorum Books, 1998.

[3] W. R. Cobb, and M. L. Johnson Ed D., Business Alchemy: Turning Ideas Into Gold. Autorhouse, 2012.

[4] M. Henricks, Not just a living: The complete guide to creating a business that gives you a life. Cambridge, MA: Perseus, 2002.
[5] S. B. Marcketti, L. S. Niehm, and R. Fuloria, "An Exploratory Study of Lifestyle Entrepreneurship and Its Relationship to Life Quality". Family and Consumer Sciences Research Journal, vol.34, pp. 241-259 , 2006. DOI: 10.1177/1077727X05283632

[6] Ministru kabineta rīkojums Nr. 566, "Konceptuāls ziṇojums "Par uzṇēmēdarbības uzsākšanas un mazās uzṇēmeējdarbības ekosistēmu un turpmāk nepieciešamajiem atbalsta stimuliem"', 2016. [Online]. Available: https://likumi.lv/doc.php?id=285096 [Accessed: Feb.12, 2019].

[7] Ekonomikas Ministrija, "Latvijas Ekonomikas attīstības pārskats", 2018. [Online]. Available: https://em.gov.lv/lv/nozares_politika/tautsaimniecibas_attistiba/latvijas_ekonomikas_attistibas_parskats/[Accessed: Feb.5, 2019].

[8] K. Žukova, "Atbalsts kūku cepējiem un lauku pirtīm - mazākajiem uzṇēmumiem mazinās nodokḷu nastu”, 2016. [Online]. Available: https://www.delfi.lv/bizness/biznesa vide/atbalsts-kuku-cepejiem-un-lauku-pirtim-mazakajiem-uznemumiem-mazinas-nodoklu-nastu.d?id=47918691 [Accessed: Feb 7, 2019]

[9] Forbes, 7 Reasons Most People Should Build Lifestyle Businesses, Not Startups, 2012. [Online]. Available: https://www. forbes.com/sites/theyec/2012/09/21/7-reasons-most-peopleshould-build-lifestyle-businesses-not-startups/\#324dc3f92eea [Accessed: Feb.12, 2019].

[10] Collins English Dictionary. "Lifestyle business". [Online]. Available:https://www.collinsdictionary.com/dictionary/english/ lifestyle-business [Accessed: Dec.20, 2018].

[11] Ewing Marion Kauffman Foundation. "Promoting entrepreneurship and education", 2004. [Online]. Available: www.emkf.org [Accessed: Jan.5, 2019].

[12] Techtarget, "Lifestyle business"., 2013. [Online]. Available: https://whatis.techtarget.com/definition/lifestyle-business [Accessed: Jan.20, 2019].

[13] The Mead Consulting Group, "Which Do You Have - a Lifestyle Business or an Equity Value Business? It's Important to Know the Difference". Issues for Growth, Vol.19, No12. [Online] Available: http://www.meadconsultinggroup.com/showNews2.php?id=147 [Accessed: Feb.23,2019].

[14] L. Bērzinna, L. Leitāne un Larisa Bule, "Mikrouznēmumi kā instruments vidusslāņa veidošanai”, 2017. [Online]. Available: https://www.bvef.lu.lv/zinas/t/20977/) [Accessed: Jan.14, 2019]

[15] Valsts izglīīības attīstības aǵentūra (VIAA), “Tūrisma nozares apraksts. Eiropas Sociālā fonda projekts „Nozaru

kvalifikācijas sistēmas izveide un profesionālās izglītības efektivitātes un kvalitātes paaugstināšana",2012. [Online]. Available: http://viaa.gov.lv/files/free/12/14912/apraksts turisms final 04042012.pdf [Accessed: Jan.25, 2019]

[16] Pārtikas veterinārais dienests, "Ražošanas uzņēmumu skaits mājas apstākḷlos Rēzeknes novadā, Rēzeknes pilsētā un Viḷānu novadā 2019.g.28.janvārī”, 2019. [Online]. Available: https:// registri.pvd.gov.lv/ur [Accessed; Jan.28, 2019].

[17] LEARN, "LEARN reǵistrēto uzṇēmumu skaits Rēzeknes novadā, Rēzeknes pilsētā un Viḷānu novadā 2019.g.28.janvārī” , 2019. 